高齢者高血圧患者に打けるアンジオテンシン II 拮抗薬（losartan）と カルシウム拮抗薬（amlodipine）の神経体液因子に及ぼす影響

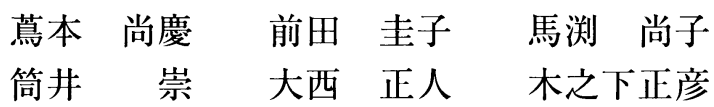

\begin{abstract}
〈要 約〉 高血圧や心不全に対する降圧薬の心血管系事故などに対する長期効果が見直されている，そこ で長期効果や予後に重要と考えられる交感神経系，レニン・アンジオテンシン系などの神経体液因子に対 する影響をカルシウム拮抗薬 amlodipine（A）と，アンジオテンシン II 受容体拮抗薬 losartan（L）につい て老年者において比較検討した. 1 年以上の長期間 A 薬投与高血圧患者 25 名 (平均年令 73 歳 ; 合併症は, 虚血性心疾患 3 名, 心不全 2 名, 糖尿病 2 名）を対象に, A 薬 $(5 \mathrm{mg} /$ 日）から L 薬 $(50 \mathrm{mg} /$ 日）に変更す る前と変更後慢性期 (平均 4.5 力月後) に血圧, 心拍数に加えて, 座位安静にて採血し, 血漿ノルエピネフ リン, レニン濃度, アルドステロン, 脳性ナトリウム利尿ペプチド（BNP）濃度を測定した. A 薬から L 薬に変更する前後で血圧（平均血圧 102 vs. $101 \mathrm{mmHg}$ ), 心拍数は不変（74 vs. 74beats $/ \mathrm{min}$ ）で降圧効果 は両薬剤で差は認めなかった. A 薬から L 薬に変更する前後でノルエピネフリン濃度は有意に低下した 799 vs. $692 \mathrm{pg} / \mathrm{mL}, \mathrm{p}<0.05)$. 又, 変更前後でレニン濃度は有意な変化は認めなかったが $(33.9 \mathrm{vs} .21 .5 \mathrm{pg} / \mathrm{mL})$, アルドステロン濃度は有意に低下した（79.3 vs. $59.0 \mathrm{pg} / \mathrm{mL}, \mathrm{p}<0.01)$. BNP 濃度は変化しなかった（72 vs. $7 \mathrm{lpg} / \mathrm{m} l)$.これらの結果より, アムロジピンは反射性交感神経系, レニン・アンジオテンシン系の充進を きたしにくく，心血管系事故予防効果が期待されているが, 神経体液因子の立場から見ると, アンジオテ ンシン II 受容体拮抗薬はアムロジピンに比しより有用である可能性が示唆された.
\end{abstract}

Key words：アムロジピン, ロサルタン, 神経体液因子, ノルエピネフリン, アルドステロン

（日老医誌 $2002 ； 39 ： 303-307$ )

\section{緒言}

本邦の高血圧治療においてはカルシウム拮抗薬が沉用 され，世界中でも約 2,800 万人もの患者にカルシウム拮 抗薬が使われていると推定される ${ }^{1}$. 降圧効果の発現が 比較的早く, また確実に得られることが高頻度で使用さ れる最も大きな理由と考えられる. しかし，近年になっ てその安全性について疑問が投げかけられている゙”。 ・脳血管系疾患の発生をエンドポイントとしたカルシウ 厶拮抗薬に関する数多くの大規模研究が報告されている が，エンドポイント抑制効果を否定する報告もあり ${ }^{31}$, カルシウム拮抗薬が高血压患者の予後を改善するか否か については,まだ完全にコンセンサスが得られていない. 高血压や心不全の患者においては, 交感神経系やレニ ン・アンジオテンシン・アルドステロン系（以下 R-AA 系) が活性化しているが, 持続型カルシウム拮抗薬 である amlodipine は反射性交感神経系の充進をきたし にくいとされているが，一般的にはカルシウム拮抗真の

T. Tsutamoto, K. Maeda, N. Mabuchi, T. Tsutsui, M. Ohnishi, M. Kinoshita：滋賀医科大学第一内科

受付日：2001. 8.13, 採用日：2001.11.20
作用機序から考慮すれば R-A-A 系に対する抑制効果は あまり期待できないと考えられる。また，短時間作働型 カルシウム拮抗薬においては, 交感神経系の緊張を増強 するとの報告もある ${ }^{4}$.

一方, R-A-A 系の活性化を抑制するアンジオテンシ ン変換醳素阻害薬（以下 ACE 阻害薬）は交感神経系に 抑制的に働くという報告もあり ${ }^{5)}$ ，高血圧患者や心不全 患者の予後改善に有效性を示す大規模研究が数多く報告 されている( ${ }^{677}$. R-A-A 系に関与する新たな降圧薬とし て開発された losartanは，経口で活性を有する新規非 ペプチドタイプのアンジオテンシン II（以下 AII）受容 体拮抗薬である. Losartan は AII タイプ 1 受容体に結 合して特異的な拮抗作用を示し ${ }^{81}$, ACE 阻害薬とは異な クブラジキニン代謝に対しては影響を及ぼさないといわ れている. 従って, ACE 阻害薬投与時にみられる乾性 咳嗽 (空咳), 血管性浮腫といった副作用を回避できる ものと予想され, 患者の QOL を考慮した場合, より有 用的な降圧薬と考えられる.

今回, 最も汎用されている持続型カルシウム拮抗薬で ある amlodipine と AII 受容体拮抗薬の losartan を用い て, 高齢者高血圧患者を対象にその降圧効果と交感神経 
BP

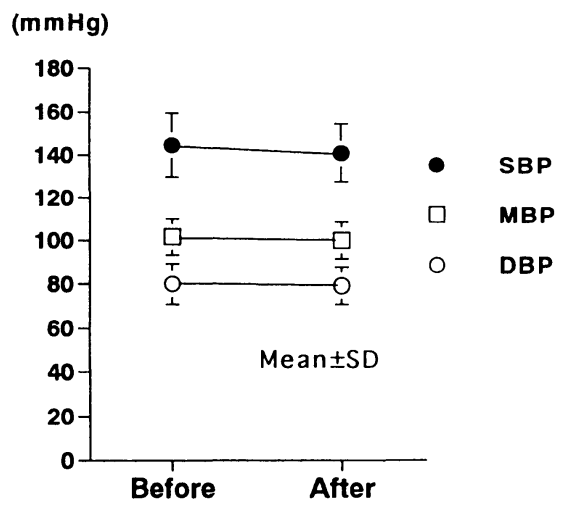

HR

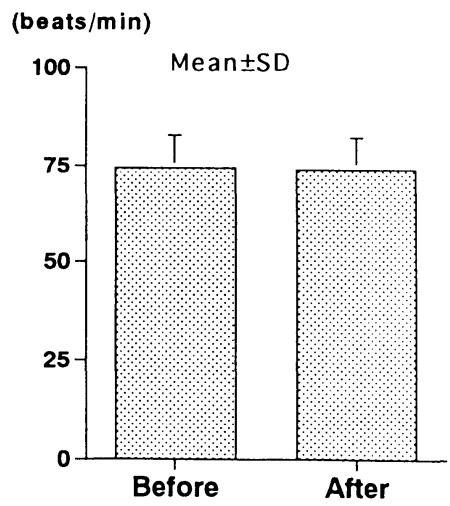

Fig. 1 Blood pressure and heart rate before and after the change of amlodipine to losartan in elderly patients with essential hypertension. $\mathrm{SBP}=$ systolic blood pressure, $\mathrm{DBP}=$ diastolic blood pressure, $\mathrm{MBP}=$ mean arterial blood pressure, $\mathrm{HR}=$ heart rate.
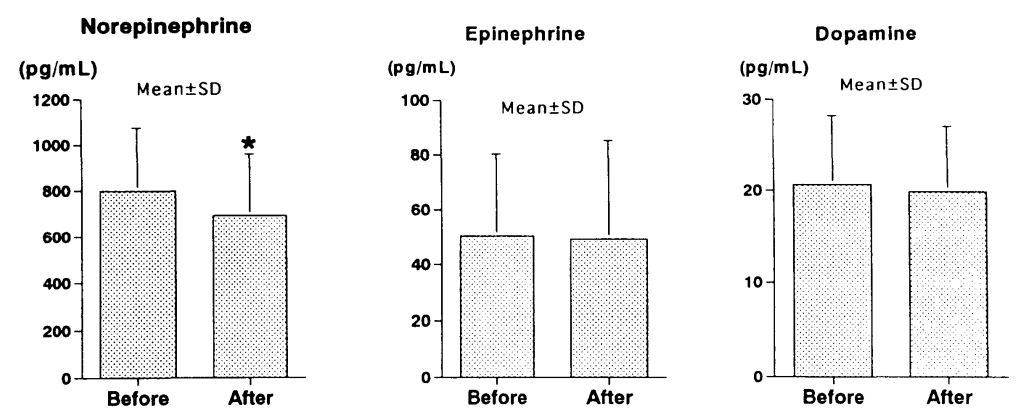

Fig. 2 Plasma levels of catecholamine before and after the change of amlodipine to losartan in elderly patients with essential hypertension. ${ }^{*}=\mathrm{p}<0.05$.

系や神経体液因子に対する影響について比較検討を行っ た。

\section{方法}

当科および関連施設の外来通院中の, 65 歳以上の高 齢者高血圧患者を対象とした. 12 力月以上 amlodipine5 $\mathrm{mg} / \mathrm{day}$ が投与されている症例において, 患者の同意を 得たのち, losartan 50mg/dayに変更した。観察期間中 は amlodipine, losartan 以外の投薬の変更は控えた.

血圧, 心拍数を losartan 投与前と投与後 4 週間毎に 計測し，ノルエピネフリン，エピネフリン，ドパミン， 活性型レニン，アルドステロンおよび脳性ナトリウム利 尿ペプチド（以下 BNP）の血槳濃度を amlodipine をlo$\operatorname{sartan}$ に変更前・変更後に, 座位安静 20 分後に採血し 測定した.

本試験のエンドポイントである, losartan 投与前・投 与後における各指標変動の有意差検定には, Student' $t$ 検定を用いた. 集計結果は平均值士標準偏差で表記した。

\section{成 績}

1 年以上にわたり amlodipine が投与されていた 65 歳 以上の高齢者高血圧患者 25 例が本試験に登録された。 年齢は $66 \sim 80$ 歳, 平均年齢 $72.5 \pm 5.2$ 歳で, 性別は男性 6 例, 女性 19 例であった. 主な合併症は, 虚血性心疾 患 3 例, 慢性心不全 (NYHA 分類 II 度) 2 例, 糖尿病 2 例であった，前治療薬である amlodipine の投与量は， 全例 $5 \mathrm{mg} /$ day 投与であった. プロトコールに従って, amlodipine $5 \mathrm{mg} /$ day 投与を losartan $50 \mathrm{mg} /$ day 投与に 変更した. losartan 平均投与期間は $4.5 \pm 2.5$ 月であった。

1. 血圧の推移

losartan 投与前後における血圧 ・ 心拍数の推移を図 1 に示す. 収縮期血圧は $145 \pm 15 \mathrm{mmHg}$ から $141 \pm 13$ $\mathrm{mmHg}$, 拡張期血圧は $80 \pm 9 \mathrm{mmHg}$ から $79 \pm 8 \mathrm{mmHg}$, 平均血圧は $102 \pm 8 \mathrm{mmHg}$ から $100 \pm 9 \mathrm{mmHg}$ へと推移 し,いずれにおいても有意な変動は認められなかった(図 1 左).また心拍数も $74 \pm 8$ beats/min から $74 \pm 8$ beats/ 

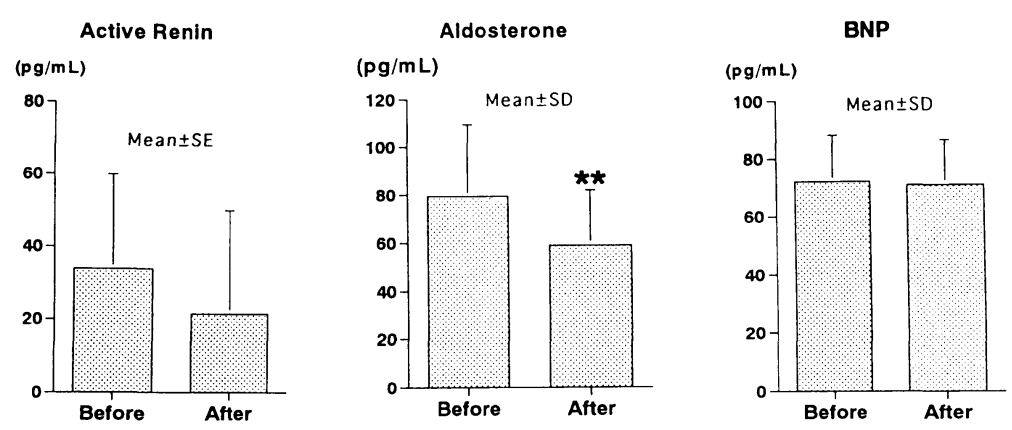

Fig. 3 Plasma levels of active renin, aldosterone, and brain natriuretic peptide (BNP) before and after the change of amlodipine to losartan in elderly patients with essential hypertension. ${ }^{* *}=\mathrm{p}<0.01$

min へと推移し，血圧同様に有意な変動はみられなかっ た (Fig. 1右).

\section{2. 神経体液因子の推移}

交感神経系因子の推移を Fig. 2 に，R-A-A 系因子およ び BNP の推移図 3 に示す. 血嶈ノルエピネフリン濃度 は $799 \pm 277 \mathrm{pg} / \mathrm{mL}$ から $692 \pm 268 \mathrm{pg} / \mathrm{mL}$ へ，有意に 低下した（p<0.05, Fig. 2 左). 血漿エピネフリンおよび ドパミン濃度には有意な変動はみられなかった（Fig. 2 中，右)。R-A-A 系因子では，血漿活性型レニン濃度は 有意な変化は認めなかったが (Fig. 3 左), 血漿アルド ステロン濃度は $81.2 \pm 35.3 \mathrm{pg} / \mathrm{mL}$ から $55.2 \pm 17.7 \mathrm{pg} / \mathrm{mL}$ へと有意に低下した（p<0.01, Fig. 3 中)，血漿 BNP 濃 度には有意な変動は認められなかった（Fig. 3 右）。

\section{考案}

高血圧の病態は一様でなく，またその成因には多くの 因子の関与が想定されている. 数多くの成因においても 中心的な役割を果たしているのが R-A-A 系である．高 血圧患者のなかには血槳レニン活性（PRA）が高値の もの, 正常範囲のもの, および低值のものがあることが 明らかにされているが, R-A-A 系の充進が本態性高血 圧患者の心血管事故に関与するとの報告もあり ${ }^{9111}$, PRA が高值を示す患者だけでなく，正常範囲にある患 者においても, 高血圧の発症・進展に組織 R-A-A 系が 重要な役割を果たしていること考えられる。これまでの 多くの研究から, 本態性高血圧の発症初期には交感神経 系の活性㐫進があることが確認されている. Tuckらは 血圧日内変動と血槳ノルエピネフリンおよびPRA との 相関を検討した研究で, 本態性高血圧の発症初期の血圧 変動はノルエピネフリンとより密接に関係しており，ま たカテコールアミンとレニン分泌とのあいだには極めて 密接な関係があると報告している ${ }^{12}$.

交感神経活性の充進に並行して R-A-A 系も活性化し
ていると考えられ，R-A-A 系の第一次的役割を担う AII の増加は単に血中ばかりでなく諸臓器に生じやすく, AII の増加は腎臟からのナトリウム・水排泄の障害, 心 血管系の収縮光進あるいはカテコールアミンやアルドス テロン分泌の促進因子として作用し, 高血圧の血圧調整 に極めて重要な役割を果たしていることは確かである. CONSENSUS study ${ }^{13}$ によればNYHA 分類 IV 度の心不 全患者で, ACE 阻害薬（enalapril）投与後 6 力月間の 死亡頻度が, 血中ノルエピネフリン, エピネフリン, AII, アルドステロンおよび心房性ナトリウム利尿ペプチド濃 度と関連することが示されている。 すなわち，これらの 血中ホルモン濃度が低下すると, 死亡率も低下するとい う相関関係を報告している。 その他, VA study ${ }^{14)}$, SOLVD $^{15}$ の成績でも，心不全の子後規定因子として神 経体液因子の重要なことが示されている.

本試験では, 持続型カルシウム拮抗薬である amlodipine を 1 年以上の継続投与を受けた高齢者高血圧患 者 24 例を, AII 受容体拮抗薬である losartan へ投与変 更し, 交感神経系およびR-A-A 系などの神経体液因子 に与える影響について検討したが， losartan 投与後に有 意な血圧の変動は認められなかった（Fig. 1). 従って, amlodipine $5 \mathrm{mg}$ 投与と losartan $50 \mathrm{mg}$ 投与による降圧 度は,ほほ同等と考えられた。

一方, 神経体液因子の交感神経系因子では血槳ノルエ ピネフリン濃度が有意に低下し（Fig. 2)，R-A-A 系では 血槳活性型レニン濃度は有意に増加し血槳アルドステロ ン濃度は有意に低下した Fig. 3).これらの現象は, losar$\tan$ の特異的な AII 受容体拮抗作用により, AII の作用 が抑制された結果, 交感神経末端からノルエピネフリン の遊出が抑制され, さらに副腎からのアルドステロン分 泌も抑制されたものと考えられる. amlodipineは, 心 不全患者に扔いても心血管事故を予防する可能性が指摘 されているがその理由の一つに，反射性の交感神経系の 
充進をきたしにくい為とされているが，本研究では，同 程度の降圧で losartan で血槳ノルエピネフリン濃度が 有意に低下したことより， losartanは amlodipine に比 して, 反射性の交感神経系の充進をきたしにくい薬剤と 考えられた。また最近アルドステロンの重要性が RALES 試験で再確認され，抗アルドステロン製剤と ACE 阻害薬との併用療法で心不全患者において約 30\% の死亡率の低下が認めらたと報告された ${ }^{16 !}$. 我々の検討 でも血中アルドステロンは循環中に約 $20 \%$ が心蔵で取 り込まれ，心筋線維化や左室リモデリングに関与してい る可能性がある ${ }^{177}$ ，心不全などの合併症を有する高血压 患者における血漿アルドステロン濃度の管理は, 非常に 重要であると思われ，今後検討が必要ではあるが，心筋 線維化や左室リモデリングにおいて両薬剤に差異がある 可能性も考えられる. BNP は主に心室から分泌され, 心室への負荷によって血中濃度が上昇するため，心不全 症例等では高値を示すとされている ${ }^{18199}$ 。 心不全患者を 対象にACE 阻害薬や AII 受容体拮抗薬を投与すると BNP 濃度が低下することが報告されている ${ }^{20211}$ ，今回の 対象症例には 6 例の心不全症例が含まれていたが，血槳 BNP 濃度に変化はみられなかった.

血管拡張薬, $\alpha 1$ 遮断薬, カルシウム拮抗薬は臥位安 静時の脈拍数, 交感神経活動の六進をきたすと報告され ている ${ }^{5}$. 最近, 短時間作働型カルシウム拮抗薬が虚血 性心疾患の発生に関系する可能性が指摘されている が5，これには血圧下降に伴う交感神経刺激が関与して いる可能性が指摘されている。一方，R-A-A 系を抑制 する ACE 阻害薬は本態性高血圧患者の血圧を下げる が，交感神経機能に悪影響を及ぼさないと報告されてい る. 本試験の結果から, AII 受容体拮抗薬も ACE 阻害 薬と同様に交感神経機能に抑制的に働くと考えられた. 交感神経の充進は心筋梗塞の発作や不整脈の誘因となる ことも考えられるため, 交感神経の過度な京進を抑制す ることは心不全患者のみならず高血圧患者にとっても有 用であると思われる.

本試験に扔いて, losartanは amlodipine から投与変 更後も安定して血圧をコントロールし, 交感神経機能に 関しては ACE 阻害薬と同様に活性化を抑制することが 示された．様々な合併症を有することの多い高齢者高血 圧患者において, 神経体液因子の管理は重要であると考 えられる. amlodipine は反射性交感神経系, R-A-A 系 の六進をきたしにくく, 心血管系事故予防効果が期待さ れている持続型カルシウム拮抗薬であるが, 本検討の結 果では, 神経体液因子に与える影響において, losartan がより有用であると考えられた。

\section{結 論}

持続型カルシウム拮抗薬である amlodipine と AII 受 容体拮抗薬の losartan を用いて，高齢者高血圧患者を 対象にその降圧効果と神経体液因子に対する影響につい て比較検討を行った. その結果, 降圧作用は同程度でも， losartan は amlodipine に比して血漿ノルエピフリン濃 度やアルドステロン濃度の増加をきたしにくく, 神経体 液因子におよぼす影響から見るとより有用な薬郕である 可能性が示唆された.

\section{文献}

1）河本修身：日本医事新報 $2000 ; 4001: 12$.

2) McInnes GT, Hole DJ, Lever AF, Meredith PA, Murray LS, Reid JL, et al. : Mortality differences between ACE inhibitor and calcium channel blocker treated hypertensive patients. J Am Coll Cardiol 2000;35 (Suppl) : $333 \mathrm{~A}-334 \mathrm{~A}$.

3) Hansson L, Hedner T, Lund-Johansen P, Kjeldsen SE, Lindholm LH, Syvertsen JO, et al. : Randomised trial of old and new antihypertensive drugs in elderly patients : cardiovascular mortality and morbidity the Swedish Trial in Old Patients with hypertension-2 study. Lancet $2000 ; 356: 352-353$.

4) Izzo JL: Sympathoadrenal activity, catecholamines, and the pathogenesis of vasculopathic hypertensive targetorgan damage. Am J Hypertens $1989 ; 2: 305 \mathrm{~S}-312 \mathrm{~S}$.

5) Cerasola G, Cottone S, D' Ignoto G, Grasso L, Carone MB, Carapelle E, et al. : Effects of enalapril maleate on blood pressure, renin-angiotensin-aldosterone system, and peripheral sympathetic activity in essential hypertension. Clin Ther $1987 ; 9: 390-399$.

6) Liebson PR, Grandits GA, Dianzumba S, Prineas RJ, Grimm RH Jr, Neaton JD, et al. : Comparison of five antihypertensive monotherapies and placebo for change in left ventricular mass in patients receiving nutritionalhygienic therapy in the Treatment of Mild Hypertension Study (TOMHS). Circulation $1995 ; 91: 698-706$.

7) Cohn JN, Johnson G, Ziesche S, Cobb F, Francis G, Tristani $\mathrm{F}$, et al.: A comparison of enalapril with hydralazine-isosorbide dinitrate in the treatment of chronic congestive heart failure. N Engl J Med 1991 ; 325 : 351-335.

8) Ohlstein EH, Gellai M, Brooks DP, Vickery L, Jugus J, Sulpizio A, et al. : The antihypertensive effect on the angiotensin II receptor antagonist DuP 753 may not be due solely to angiotensin II receptor antagonism. J Pharmacol Exp Ther $1992 ; 262: 595-601$.

9) Brunner HR, Laragh JH, Baer L. Newton MA, Goodwin FT, Krakoff LR, et al. : Essential hypertension : renin and aldosterone, heart attack and stroke. N Engl J Med 1972; $286: 441-449$. 
10) Alderman MH, Madhavan S, Ooi WL, Cohen H, Sealey JE, Laragh JH. : Association of the renin-sodium profile with the risk of myocardial infarction in patients with hypertension. N Engl J Med 1991 ; 324 : 1098 -1104.

11) Meade TW, Cooper JA, Peart WS : Plasma renin activity and ischemic heart disease. N Engl J Med 1993;329: $616-619$

12) Tuck M, Stern N, Sowers JR: Enhanced 24hr norepinephrine and renin secretion in young patients with essential hypertension. Am J Cardiol $1985 ; 55: 112-115$.

13) Swedberg K, Eneroth P, Kjekshus J, Wilhelmsen L: Hormones regulating cardiovascular function in patients with severe congestive heart failure and their relation to mortality. Circulation $1990 ; 82: 1730-1736$.

14) Cohn JN, Archibald DG, Ziesche S, Franciosa JA, Harston WE, Tristani FE, et al. : Effect of vasodilator therapy on mortality in chronic congestive heart failure. $\mathrm{N}$ Engl J Med $1986 ; 314: 1547-1552$.

15) The SOLVD investigators: Effect of enalapril on survival in patients with reduced left ventricular ejection fractions and congestive heart failure. N Engl J Med $1991 ; 325: 293-302$.

16) Pitt B, Zannad F, Remme WJ, Cody R, Castaigne A, Pere $z$ A, et al. : The effect of spironolactone on morbidity and mortality in patients with severe heart failure. Randomized Aldactone Evaluation Study Investigators. N Engl J Med $1999 ; 341: 709-717$.

17) Tsutamoto T, Wada A, Maeda K, Mabuchi N, Hayashi M, Tsutsui $\mathrm{T}$, et al.: Spironolactone inhibits the transcar- diac extraction of aldosterone in patients with congestive heart failure. J Am Coll Cardiol $2000 ; 36$ : 838-844.

18) Tsutamoto T, Wada A, Maeda K, Hisanaga T, Mabuchi $\mathrm{N}$, Hayashi $\mathrm{M}$, et al.: Plasma brain natriuretic peptide level as a biochemical marker of morbidity and mortality in patients with asymptomatic or minimally symptomatic left ventricular dysfunction. Comparison with plasma angiotensin II and endothelin-1. Eur Heart J $1999 ; 20: 1799-1807$.

19) Tsutamoto $T$, Wada A, Maeda $K$, Hisanaga $T$, Maeda $Y$, Fukai D, et al. : Attenuation of compensation of endogenous cardiac natriuretic peptide system in chronic heart failure : prognostic role of plasma brain natriuretic peptide concentration in patients with chronic symptomatic left ventricular dysfunction. Circulation. $1997 ; 96: 509$ 516.

20) Kohno M, Horio T, Yokokawa K, Yasunari K, Ikeda M, Minami M, et al. : Brain natriuretic peptide as a marker for hypertensive left ventricular hypertrophy: changes during 1-year antihypertensive therapy with angiotensin-converting enzyme inhibitor. Am J Med 1995 ; 98 : $257-265$.

21) Tsutamoto T, Wada A, Maeda K, Mabuchi N, Hayashi M, Tsutsui T, et al. : Angiotensin II type 1 receptor antagonist decreases plasma levels of tumor necrosis factor alpha, interleukin- 6 and soluble adhesion molecules in patients with chronic heart failure. J Am Coll Cardiol 2000; $35: 714-721$.

Abstract

\title{
Comparative Effects of Losartan and Amlodipine on Activities of Sympathetic Nerve, Renin-angiotensin-aldosterone System and Brain Natriuretic Peptide in the Elderly Hypertensive Patients
}

\author{
Takayoshi Tsutamoto, Keiko Maeda, Naoko Mabuchi, Takashi Tsutsui,
} Masato Ohnishi and Masahiko Kinoshita

This study investigated the comparative effects of losartan and amlodipine on the activation of the sympathetic nervous system, renin-angiotensin-aldosterone system (R-A-A system) and brain natriuretic peptide (BNP) in patients with essential hypertension. Twenty-four elderly patients who had received more than 12 months of antihypertensive treatment with amlodipine participated in this study. The treatment regimen of $5 \mathrm{mg} /$ day amlodipine was changed to $50 \mathrm{mg} / \mathrm{day}$ losartan. Plasma catecholamines (norepinephrine, epinephrine and dopamine), active renin, aldosterone and BNP concentration were measured before and after an average of 5 months of losartan treatment. After losartan treatment, blood pressures were not changed, suggesting the comparable effect of $50 \mathrm{mg}$ losartan and $5 \mathrm{mg}$ amlodipine on elevated blood pressure. Losartan significantly reduced norepinephrine $(799 \pm 277 \mathrm{pg} / \mathrm{mL}$ vs. $692 \pm 268 \mathrm{pg} / \mathrm{mL}, \mathrm{p}<0.05)$ and aldosterone concentration $(81.2 \pm 35.3$ $\mathrm{pg} / \mathrm{mL}$ vs. $55.2 \pm 17.7 \mathrm{pg} / \mathrm{mL}, \mathrm{p}<0.01$ ), whereas there were not any changes in BNP concentrations. These findings suggested that losartan might be superior to amlodipine in prevention of chronic or intermittent sympathetic hyperactivity and enhanced R-A-A system.

Key words : Losartan, Amlodipine, Norepinephrine, Aldosterone, Brain natriuretic peptide (Jpn J Geriat $2002 ; 39: 303-307$ )

First Department of Internal Medicine, Shiga University of Medical Science 